\title{
Effect of N, P and $K$ fertilizer on the flower yield of Chrysanthemum
}

\author{
R. Ahmed ${ }^{1}$, M.J. Hussain ${ }^{2}$, S. Ahmed ${ }^{3}$, M.R. Karim ${ }^{1}$ and M.A. Siddiky ${ }^{2}$ \\ ${ }^{1}$ Horticulture Research Centre, ${ }^{2}$ Soil \& Water Management Section of Horticulture Research Centre, \\ ${ }^{3}$ Biotechnology Division, Bangladesh Agricultural Research Institute, Gazipur -1701, Bangladesh.
}

*Corresponding author and Email: hussainmdjamal@ymail.com

Received: 9 December 2016

Accepted: 12 June 2017

\begin{abstract}
An experiment was conducted at the research field of Horticulture Research Centre, BARI, Gazipur during Rabi season of 2012-13 to 2014-15 to evaluate the response of different doses of N, P and K on the yield and yield attributes of chrysanthemum (var. BARI Chrysanthemum-1) and to find out the optimum and economic doses of NPK for maximizing yield of chrysanthemum. Treatments comprising four levels each of $\mathrm{N}\left(0,100,150\right.$ and $\left.200 \mathrm{~kg} \mathrm{ha}^{-1}\right), \mathrm{P}\left(0,50,75\right.$ and $\left.100 \mathrm{~kg} \mathrm{ha}^{-1}\right)$ and $\mathrm{K}$ $\left(0,90,135\right.$ and $\left.180 \mathrm{~kg} \mathrm{ha}^{-1}\right)$ along with blanket dose of $2 \mathrm{~kg} \mathrm{~B}$ and $4 \mathrm{~kg} \mathrm{Zn} \mathrm{ha}{ }^{-1}$ were used. The treatments were assigned in a randomized complete block design with three replications. The combined effect of NPK significantly increased yield and yield attributes of chrysanthemum for each of the yearly experiments as well as the average of three years results. Significantly, the highest flower yield $(12.45,11.47$ and $11.96 \mathrm{t} / \mathrm{ha})$ was obtained with the application of $\mathrm{N}_{150} \mathrm{P}_{75} \mathrm{~K}_{135} \mathrm{~kg} \mathrm{ha}^{-1}$ $\left(\mathrm{T}_{3}\right)$ along with blanket dose of $2 \mathrm{~kg} \mathrm{~B}$ and $4 \mathrm{~kg} \mathrm{Zn} \mathrm{ha}^{-1}$ for the years of 2012-13, 2013-14 and 201415 , respectively and it was statistically identical with $\mathrm{T}_{4}\left(\mathrm{~N}_{200} \mathrm{P}_{75} \mathrm{~K}_{135} \mathrm{~kg}\right.$ ha $\left.{ }^{-1}\right)$ treatment. Application of $150 \mathrm{~kg} \mathrm{~N}, 75 \mathrm{~kg} \mathrm{P}$ and $135 \mathrm{~kg} \mathrm{~K}$ increased yield by 52.76, 42.29 and 36.51\%, 152.08, 126.23 and $99.13 \%$ and $88.35,51.30$ and $60.75 \%$, respectively, over their control in respect to the years. The highest benefit-cost ratio 5.54 followed by 5.14 was obtained from $\mathrm{T}_{3}\left(\mathrm{~N}_{150} \mathrm{P}_{75} \mathrm{~K}_{135} \mathrm{~kg} \mathrm{ha}^{-1}\right)$ followed by $\mathrm{T}_{4}$ treatment, respectively. From the quadratic regression equation averaging three years data the optimum and economic doses 155 and $151.8 \mathrm{~kg} \mathrm{~N}, 79.3$ and $77.68 \mathrm{~kg} \mathrm{P}$ and 118.75 and $115.7 \mathrm{~kg} \mathrm{~K}$, respectively were found which could be recommended for chrysanthemum production in Grey Terrace Soil of Joydebpur under AEZ 28.
\end{abstract}

Keywords: Chrysanthemum, NPK fertilizer, optimum and economic dose.

\section{Introduction}

Chrysanthemum is one of the most important commercial flower grown mainly for loose and cut flower production, which are used in floral arrangement and marking garlands, veni and bouquet. In many countries it is next only to rose in value of crop produced. Sustainable flower production requires optimal fertilizer management to attain a high ornamental value of plant and to reduce production costs (Zhang et al., 2012). Nitrogen, phosphorus and potassium play a vital role in the production of good quality flowers. Nitrogen is considered to be the most crucial because it is a constituent of protein and nucleic acid which is helpful in plant growth (Haque, 2001) as well as to promotes rapid growth. This is because of higher concentration of nitrogen, which has tendency to increase leaf cell number and cell size with an overall increase 
in leaf production as reported by Meyer et al. (1973). Potassium has been reported to be involved in synthesis of peptide bond, protein and carbohydrate metabolism and also participates in rapid cell division and differentiation (Belorkar et al., 1992). Phosphorus and potash contents resulted in maximum increase in nutrient uptake by virtue of more photosynthesis through more chlorophyll formation with an increased leaf area (Belorkar et al., 1992).

Nitrogen is essential for the creation of biomass as well as for the biosynthesis of enzymes in chrysanthemum leaves (Liu et al., 2010). Chrysanthemums take up nitrogen at an even rate from the time of planting to the flowering stage and after that time nitrogen uptake decreases (Yoon et al., 2000). In chrysanthemum, the need for phosphorus is significantly lower than that of nitrogen ( $\mathrm{Li}$ et al., 2009). Potassium requirements are high, and its presence in the plant favorably affects growth and flower color (Vaněk et al., 2012).

Nitrogen applied as fertilizer is the main sources used to meet the $\mathrm{N}$ requirements of plant growth (Konnerup and Brix, 2010). The highest level of nitrogen has pronounced effect on number of flowers (Khan et al., 1999). High nitrogen with appropriate dose of phosphorus and potassium seemed to have increased vegetative growth as earlier stage also reported by Denisen (1982). The growth and development of stock or production plants largely depend on proper feeding right from the beginning. Chrysanthemum is heavy feeder and has large requirements for nitrogen, phosphorus and potassium. Investigations on the requirement of different nutrients, carried out at various places, resulted in variable recommendations. The nutrient requirements at different growth stages of chrysanthemum was determined by Kazimirova (1975) who observed that requirement of all the basic three nutrients $(\mathrm{N}, \mathrm{P}$ and $\mathrm{K}$ ) were the maximum during vigorous growth, especially $\mathrm{N}, \mathrm{K}$ requirement dose remained high until flowering. Kochkin and
Kazimirova (1971) found a high positive correlation between flower production and $\mathrm{N}$ and P contents of soil. Lodhi and Tiwari (1993) observed maximum size and number of flowers with $15 \mathrm{~kg} \mathrm{~N}$ along with $8 \mathrm{~g} \mathrm{P} \mathrm{m}^{-2}$. An application at the rate of $10 \mathrm{~g} \mathrm{~m}^{-2}$ was recommended for both $\mathrm{N}$ and $\mathrm{P}$ for optimum cut flower production (Jhon and Paul, 1999). However, information regarding nutritional requirement for chrysanthemum cultivation in Bangladesh is meager. Therefore, the present study was undertaken to evaluate the response of $\mathrm{N}, \mathrm{P}$ and $\mathrm{K}$ on the yield and yield attributes of chrysanthemum and to find out the optimum and economic doses of NPK for maximizing yield of chrysanthemum in Grey Terrace soil of Joydebpur, Gazipur.

\section{Materials and Methods}

Three years experiments were conducted at the Horticultural Research Farm, BARI, Joydebpur, Gazipur during Rabi season of 2012-13 to 201415 to evaluate the response of $\mathrm{N}, \mathrm{P}$ and $\mathrm{K}$ on the yield and yield attributes of chrysanthemum and to find out the optimum and economic doses of NPK for maximizing yield of chrysanthemum. The initial soil characteristics were shown in Table 1. The soil test values showed that the experimental soil was deficient in nutrients especially $\mathrm{N}, \mathrm{P}$ and $\mathrm{K}$. The field experiment was set up in a randomized complete block design with three replications. Treatments comprising four levels of fertilizer nutrients each of $\mathrm{N}(0$, 100,150 and $\left.200 \mathrm{~kg} \mathrm{ha}^{-1}\right), \mathrm{P}(0,50,75$ and 100 $\left.\mathrm{kg} \mathrm{ha}^{-1}\right)$ and $\mathrm{K}\left(0,90,135\right.$ and $\left.180 \mathrm{~kg} \mathrm{ha}^{-1}\right)$ along with a blanket dose of $2 \mathrm{~kg} \mathrm{~B}$ and $4 \mathrm{~kg} \mathrm{Zn} \mathrm{ha}{ }^{-1}$ were used. The unit plot size and plant spacing were $2 \mathrm{~m} \mathrm{x} 1.50 \mathrm{~m}$ and $40 \mathrm{~cm} \mathrm{x} 30 \mathrm{~cm}$, respectively. Every plot except control plot had received blanket dose of $2 \mathrm{~kg} \mathrm{~B}$ and $4 \mathrm{~kg} \mathrm{Zn} \mathrm{ha}^{-1}$. The variety BARI Chrysanthemum-1 was used as the test crop. Urea, TSP, MoP, boric acid and zinc sulphate were used as a source of N, P, K, B and $\mathrm{Zn}$, respectively. Total amount of $\mathrm{P}, \mathrm{K}, \mathrm{B}$, $\mathrm{Zn}$ and $1 / 3^{\text {rd }} \mathrm{N}$ were applied at the time of final land preparation and the remaining $\mathrm{N}$ were applied in two equal splits each at 30 and 45 
days after planting, respectively. Thirty days old seedlings were transplanted on $27^{\text {th }}$ November, 2012; $2^{\text {nd }}$ December, 2013 and $6^{\text {th }}$ November, 2014, respectively. Intercultural operations such as weeding, irrigation etc. were done as and when required. Flowers were harvested four times from $13^{\text {th }}$ February to $8^{\text {th }}$ March, 2013, $13^{\text {th }}$ February to $12^{\text {th }}$ March, 2014, $24^{\text {th }}$ January to $2^{\text {nd }}$ March, 2015, respectively. Data on growth, yield and yield contributing characters were recorded from ten selected plants at each treatment. The collected data were analyzed statistically using the statistical package MSTAT-C.

\section{Results and Discussion}

Effect of different levels of NPK on the yield and yield contributing characters of chrysanthemum are presented in Table 2 . Different fertilizer management packages showed a significant influence on yield and yield attributes of chrysanthemum. The highest plant height, number of flowers plant ${ }^{-1}$, flower length, flower diameter, individual flower weight and yield per hectare were recorded in $\mathrm{T}_{3}$ treatment which received $150 \mathrm{~kg} \mathrm{~N} 75 \mathrm{~kg} \mathrm{P}$ and $135 \mathrm{~kg} \mathrm{~K}$ $\mathrm{ha}^{-1}$ and the lowest from control $\left(\mathrm{T}_{11}\right)$ in each of the three years (Table 2). The maximum plant heights $(46.60,46.20$ and $48.40 \mathrm{~cm})$ which were recorded from $\mathrm{T}_{3}\left(\mathrm{~N}_{150} \mathrm{P}_{75} \mathrm{~K}_{135} \mathrm{~kg} \mathrm{ha}^{-1}\right)$ treatment that was statistically identical with $\mathrm{T}_{4}$ $\left(\mathrm{N}_{200} \mathrm{P}_{75} \mathrm{~K}_{135} \mathrm{~kg} \mathrm{ha}{ }^{-1}\right)$ for 2012-13 and $\mathrm{T}_{4}$ $\left(\mathrm{N}_{200} \mathrm{P}_{75} \mathrm{~K}_{135} \mathrm{~kg} \mathrm{ha}^{-1}\right)$ and $\mathrm{T}_{2}\left(\mathrm{~N}_{100} \mathrm{P}_{75} \mathrm{~K}_{135} \mathrm{~kg} \mathrm{ha}^{-1}\right)$ for 2013-14 and 2014-15, respectively. These results were in agreement with the findings of
Khankhane et al. (1997) who reported the highest growth of chrysanthemum obtained from $15 \mathrm{~g} \mathrm{~N} \mathrm{~m}^{-2}\left(150 \mathrm{~kg} \mathrm{ha}^{-1}\right)$ and $16 \mathrm{~K} \mathrm{~m}^{-2}\left(160 \mathrm{~kg} \mathrm{ha}^{-}\right.$ $\left.{ }^{1}\right)$. Nitrogen promotes rapid growth as a constituent of protein and nucleic acid (Haque, 2001). This rapid growth is because of higher concentration of nitrogen, which has tendency to increase leaf cell number and cell size with an overall increase in leaf production as reported by Meyer et al. (1973). Potassium enhances the synthesis and translocation of carbohydrate; whereas, phosphorus encourages cell walls and length of plant (Henry, 1982). The highest number of flowers plant ${ }^{-1}(25.72,23.02$ and 24.37), flower diameter $(7.78,7.10$ and $7.44 \mathrm{~cm})$ and individual flower weight $(6.05,5.98$ and $5.97 \mathrm{~g}$ ) were also found in the treatment $\mathrm{T}_{3}$ $\left(\mathrm{N}_{150} \mathrm{P}_{75} \mathrm{~K}_{135} \mathrm{~kg} \mathrm{ha}^{-1}\right)$, respectively for the years and it was statistically identical with treatment $\mathrm{T}_{4}$ $\left(\mathrm{N}_{200} \mathrm{P}_{75} \mathrm{~K}_{135} \mathrm{~kg} \mathrm{ha}^{-1}\right)$. As the number of branches were higher in the treatments with NPK that resulted in more photosynthesis and food accumulation, which might have resulted in better growth and converted vegetative growth in early stages due to balanced nutrition and also had sufficient food material to produce the flower earlier, while in control treatments took more days to flower which might be due to late emergence of flower buds. These findings are in close conformity with those reported by Mishra (1998) in gaillardia. Ahmad et al. (2004) reported early flowering in dahlia by applying urea, DAP and farm yard manure in a combination.

Table 1. Initial soil nutrient status of the experimental site of HRC Farm, Joydebpur, Gazipur

\begin{tabular}{lccc}
\hline Nutrient & Soil test value & Critical level & Soil test interpretation \\
\hline $\mathrm{pH}$ & 6.2 & - & Slightly acidic \\
Organic matter $(\%)$ & 0.95 & - & Low \\
$\mathrm{Ca}(\mathrm{c}-\mathrm{mol} / \mathrm{kg}$ soil $)$ & 1.12 & 2.0 & Low \\
$\mathrm{Mg}(\mathrm{c}-\mathrm{mol} / \mathrm{kg}$ soil $)$ & 0.60 & 0.5 & Medium \\
Total N $(\%)$ & 0.08 & 0.12 & Medium \\
Available P $(\mu \mathrm{g} / \mathrm{g})$ & 9 & 7 & Low \\
$\mathrm{K}(\mathrm{c}-\mathrm{mol} / \mathrm{kg} \mathrm{soil)}$ & 0.17 & 0.12 & Low \\
$\mathrm{S}(\mu \mathrm{g} / \mathrm{g})$ & 11.2 & 10 & Low \\
$\mathrm{Zn}(\mu \mathrm{g} / \mathrm{g})$ & 1.4 & 0.6 & Low \\
$\mathrm{B}(\mu \mathrm{g} / \mathrm{g})$ & 0.10 & 0.2 & Low \\
\hline
\end{tabular}


Table 2. Effect of different fertilizer treatments on different yield attributes of chrysanthemum

\begin{tabular}{|c|c|c|c|c|c|c|c|c|c|}
\hline \multirow{2}{*}{$\begin{array}{l}\text { Treatments } \\
\left(\mathrm{Kg} \mathrm{ha}^{-1}\right)\end{array}$} & \multicolumn{3}{|c|}{ Plant height $(\mathrm{cm})$} & \multicolumn{3}{|c|}{$\begin{array}{c}\text { Flower/plant } \\
\quad(\text { nos.) }\end{array}$} & \multicolumn{3}{|c|}{$\begin{array}{l}\text { Stalk length } \\
(\mathrm{cm})\end{array}$} \\
\hline & $2012-13$ & 2013-14 & $2014-15$ & $2012-13$ & 2013-14 & $2014-15$ & $2012-13$ & 2013-14 & $2014-15$ \\
\hline $\mathrm{T}_{1}=\mathrm{N}_{0} \mathrm{P}_{75} \mathrm{~K}_{135}$ & $34.26 \mathrm{f}$ & $30.05 \mathrm{gh}$ & $34.15 \mathrm{de}$ & $16.45 \mathrm{~g}$ & $13.87 \mathrm{f}$ & $15.16 \mathrm{ef}$ & $10.36 \mathrm{~g}$ & $10.55 \mathrm{de}$ & $10.51 \mathrm{bc}$ \\
\hline $\mathrm{T}_{2}=\mathrm{N}_{100} \mathrm{P}_{75} \mathrm{~K}_{135}$ & $44.60 \mathrm{~b}$ & $42.47 \mathrm{abc}$ & $45.54 \mathrm{ab}$ & $22.05 b c$ & $20.65 b$ & $21.35 b c$ & $11.15 \mathrm{c}$ & $11.10 \mathrm{a}-\mathrm{d}$ & $11.43 \mathrm{ab}$ \\
\hline $\mathrm{T}_{3}=\mathrm{N}_{150} \mathrm{P}_{75} \mathrm{~K}_{135}$ & $46.60 \mathrm{a}$ & $46.20 \mathrm{a}$ & $48.40 \mathrm{a}$ & $25.72 \mathrm{a}$ & $23.02 \mathrm{a}$ & $24.37 \mathrm{a}$ & $11.88 \mathrm{a}$ & $11.50 \mathrm{a}$ & $11.68 \mathrm{a}$ \\
\hline $\mathrm{T}_{4}=\mathrm{N}_{200} \mathrm{P}_{75} \mathrm{~K}_{135}$ & $45.53 \mathrm{ab}$ & $44.87 \mathrm{ab}$ & $47.20 \mathrm{a}$ & $23.98 \mathrm{ab}$ & $21.95 \mathrm{a}$ & $22.97 \mathrm{ab}$ & $11.55 \mathrm{~b}$ & $11.12 \mathrm{a}-\mathrm{c}$ & $11.20 \mathrm{ab}$ \\
\hline $\mathrm{T}_{5}=\mathrm{N}_{150} \mathrm{P}_{0} \mathrm{~K}_{135}$ & $36.60 \mathrm{e}$ & $31.55 \mathrm{gh}$ & $36.08 \mathrm{cde}$ & $16.75 \mathrm{fg}$ & $14.13 \mathrm{f}$ & $15.44 \mathrm{ef}$ & $10.48 \mathrm{fg}$ & 10.49 e & $10.94 \mathrm{ab}$ \\
\hline $\mathrm{T}_{6}=\mathrm{N}_{150} \mathrm{P}_{50} \mathrm{~K}_{135}$ & $39.48 \mathrm{~d}$ & $34.77 \mathrm{efg}$ & $39.13 \mathrm{bcd}$ & 18.65def & $16.45 \mathrm{de}$ & $17.55 \mathrm{de}$ & $10.72 \mathrm{def}$ & 10.76 b-e & $10.49 \mathrm{bc}$ \\
\hline $\mathrm{T}_{7}=\mathrm{N}_{150} \mathrm{P}_{100} \mathrm{~K}_{135}$ & $40.28 \mathrm{~d}$ & $36.55 \mathrm{def}$ & $40.42 \mathrm{bcd}$ & $19.75 \mathrm{cde}$ & $17.55 \mathrm{~cd}$ & $18.65 \mathrm{~cd}$ & $10.82 \mathrm{cde}$ & $10.87 \quad b-e$ & $10.95 \mathrm{ab}$ \\
\hline $\mathrm{T}_{8}=\mathrm{N}_{150} \mathrm{P}_{75} \mathrm{~K}_{0}$ & $37.15 \mathrm{e}$ & $33.03 \mathrm{fg}$ & $37.09 \mathrm{cde}$ & $17.35 \mathrm{efg}$ & $15.75 \mathrm{e}$ & $16.55 \mathrm{de}$ & $10.55 \mathrm{efg}$ & 10.99 a-e & $10.97 \mathrm{ab}$ \\
\hline $\mathrm{T}_{9}=\mathrm{N}_{150} \mathrm{P}_{75} \mathrm{~K}_{90}$ & $42.40 \mathrm{c}$ & $38.55 \mathrm{cde}$ & $42.48 \mathrm{abc}$ & $20.45 \mathrm{~cd}$ & $18.02 \mathrm{c}$ & $19.24 \mathrm{~cd}$ & $10.95 \mathrm{~cd}$ & $10.93 \mathrm{~b}-\mathrm{e}$ & $10.96 \mathrm{ab}$ \\
\hline $\mathrm{T}_{10}=\mathrm{N}_{150} \mathrm{P}_{75} \mathrm{~K}_{180}$ & $43.80 \mathrm{bc}$ & $40.95 \mathrm{bcd}$ & 44.38ab & $21.33 \mathrm{c}$ & $19.55 \mathrm{~b}$ & $20.44 \mathrm{bc}$ & $11.05 \mathrm{~cd}$ & $11.17 \mathrm{ab}$ & $10.98 \mathrm{ab}$ \\
\hline $\mathrm{T}_{11}=$ Native fertility & $31.55 \mathrm{~g}$ & $27.06 \mathrm{~h}$ & $31.31 \mathrm{e}$ & $14.05 \mathrm{~h}$ & $11.89 \mathrm{~g}$ & $12.97 \mathrm{f}$ & $10.02 \mathrm{~h}$ & $10.58 \mathrm{c}-\mathrm{e}$ & $9.970 \mathrm{c}$ \\
\hline $\mathrm{CV}(\%)$ & 8.42 & 9.42 & 7.95 & 9.25 & 10.45 & 8.25 & 6.85 & 2.67 & 4.40 \\
\hline
\end{tabular}

Means having common letter in a column are not significantly different by DMRT at $5 \%$ level. 
Table 3. Effect of different fertilizer treatments on yield and yield attributes of chrysanthemum

\begin{tabular}{|c|c|c|c|c|c|c|c|c|c|c|}
\hline \multirow{2}{*}{$\begin{array}{l}\text { Treatments } \\
\left(\mathrm{Kg} \mathrm{ha}^{-1}\right)\end{array}$} & \multicolumn{3}{|c|}{$\begin{array}{l}\text { Flower diameter } \\
\qquad(\mathrm{cm})\end{array}$} & \multicolumn{3}{|c|}{$\begin{array}{l}\text { Individual flower weight } \\
(\mathrm{g})\end{array}$} & \multicolumn{3}{|c|}{$\begin{array}{l}\text { Flower yield } \\
\qquad\left(\mathrm{t} \mathrm{ha}^{-1}\right)\end{array}$} & \multirow{2}{*}{$\begin{array}{c}\text { Average } \\
\text { flower } \\
\text { yield } \\
\left(\mathrm{t} \mathrm{ha}^{-1}\right)\end{array}$} \\
\hline & $2012-13$ & 2013-14 & 2014-15 & $2012-13$ & 2013-14 & 2014-15 & $2012-13$ & 2013-14 & 2014-15 & \\
\hline $\mathrm{T}_{1}=\mathrm{N}_{0} \mathrm{P}_{75} \mathrm{~K}_{135}$ & $6.45 \mathrm{e}$ & $4.78 \mathrm{gh}$ & $5.62 \mathrm{ef}$ & $3.85 \mathrm{e}$ & $3.32 \mathrm{gh}$ & $3.59 \mathrm{ef}$ & $8.15 \mathrm{i}$ & $4.88 \mathrm{i}$ & $6.02 \mathrm{~h}$ & $6.35 \mathrm{~g}$ \\
\hline $\mathrm{T}_{2}=\mathrm{N}_{100} \mathrm{P}_{75} \mathrm{~K}_{135}$ & $7.52 \mathrm{a}-\mathrm{c}$ & $6.55 a-c$ & $7.03 a-c$ & $5.45 \mathrm{~b}$ & $5.32 \mathrm{bc}$ & $5.38 \mathrm{abc}$ & $11.35 b c$ & $9.48 \mathrm{c}$ & $9.92 \mathrm{bc}$ & $10.25 \mathrm{c}$ \\
\hline $\mathrm{T}_{3}=\mathrm{N}_{150} \mathrm{P}_{75} \mathrm{~K}_{135}$ & $7.78 \mathrm{a}$ & 7.10a & $7.44 \mathrm{a}$ & $6.05 \mathrm{a}$ & $5.98 \mathrm{a}$ & $5.97 \mathrm{a}$ & $12.45 \mathrm{a}$ & $11.80 \mathrm{a}$ & $11.63 \mathrm{a}$ & $11.96 \mathrm{a}$ \\
\hline $\mathrm{T}_{4}=\mathrm{N}_{200} \mathrm{P}_{75} \mathrm{~K}_{135}$ & $7.65 \mathrm{ab}$ & $6.72 \mathrm{ab}$ & 7.19ab & $5.75 \mathrm{ab}$ & $5.63 \mathrm{ab}$ & $5.69 \mathrm{ab}$ & $11.95 \mathrm{ab}$ & $10.62 \mathrm{~b}$ & $10.79 \mathrm{ab}$ & $11.12 \mathrm{~b}$ \\
\hline $\mathrm{T}_{5}=\mathrm{N}_{150} \mathrm{P}_{0} \mathrm{~K}_{135}$ & $6.95 \mathrm{de}$ & $5.01 \mathrm{fg}$ & $5.98 \mathrm{de}$ & $3.95 \mathrm{e}$ & $3.46 \mathrm{f}-\mathrm{h}$ & $3.71 \mathrm{def}$ & $8.75 \mathrm{hi}$ & $5.40 \mathrm{hi}$ & $7.57 \mathrm{fg}$ & $7.24 \mathrm{f}$ \\
\hline $\mathrm{T}_{6}=\mathrm{N}_{150} \mathrm{P}_{50} \mathrm{~K}_{135}$ & $7.21 \mathrm{~cd}$ & $5.52 \mathrm{~d}-\mathrm{g}$ & $6.37 \mathrm{~b}-\mathrm{e}$ & $4.55 \mathrm{~d}$ & $3.98 \mathrm{ef}$ & $4.27 \mathrm{c}-\mathrm{f}$ & $9.55 \mathrm{fg}$ & $6.58 \mathrm{fg}$ & $8.23 \mathrm{ef}$ & $8.12 \mathrm{e}$ \\
\hline $\mathrm{T}_{7}=\mathrm{N}_{150} \mathrm{P}_{100} \mathrm{~K}_{135}$ & $7.25 \mathrm{~cd}$ & $5.78 \mathrm{c}-\mathrm{f}$ & $6.52 \mathrm{a}-\mathrm{e}$ & $4.65 \mathrm{~d}$ & $4.26 \mathrm{e}$ & $4.46 \mathrm{~b}-\mathrm{f}$ & $10.15 \mathrm{ef}$ & 7.31 ef & $9.12 \mathrm{c}-\mathrm{e}$ & $8.86 \mathrm{~d}$ \\
\hline $\mathrm{T}_{8}=\mathrm{N}_{150} \mathrm{P}_{75} \mathrm{~K}_{0}$ & $7.15 \mathrm{~cd}$ & $5.25 \mathrm{efg}$ & $6.2 \mathrm{cde}$ & $4.05 \mathrm{e}$ & $3.63 \mathrm{fg}$ & $3.84 \mathrm{def}$ & $9.12 \mathrm{gh}$ & $6.09 \mathrm{gh}$ & $7.11 \mathrm{~g}$ & 7.44 ef \\
\hline $\mathrm{T}_{9}=\mathrm{N}_{150} \mathrm{P}_{75} \mathrm{~K}_{90}$ & $7.38 \mathrm{bc}$ & $6.02 \mathrm{~b}-\mathrm{e}$ & $6.7 \mathrm{a}-\mathrm{d}$ & $4.85 \mathrm{~cd}$ & $4.56 \mathrm{de}$ & $4.71 \mathrm{a}-\mathrm{e}$ & $10.55 \mathrm{de}$ & $7.78 \mathrm{de}$ & $8.62 \mathrm{de}$ & $8.98 \mathrm{~d}$ \\
\hline $\mathrm{T}_{10}=\mathrm{N}_{150} \mathrm{P}_{75} \mathrm{~K}_{180}$ & $7.44 a-c$ & $6.28 \mathrm{a}-\mathrm{d}$ & $6.86 \mathrm{a}-\mathrm{d}$ & $5.05 \mathrm{c}$ & $4.95 \mathrm{~cd}$ & $4.99 \mathrm{a}-\mathrm{d}$ & $11.05 \mathrm{~cd}$ & $8.39 \mathrm{~d}$ & $9.22 \mathrm{~cd}$ & $9.55 \mathrm{~cd}$ \\
\hline $\mathrm{T}_{11}=$ Native fertility & $5.65 f$ & $4.05 \mathrm{~h}$ & $4.85 \mathrm{f}$ & $3.53 \mathrm{f}$ & $2.95 \mathrm{~h}$ & $3.24 \mathrm{f}$ & $7.35 \mathrm{j}$ & $3.25 \mathrm{j}$ & $4.80 \mathrm{i}$ & $5.13 \mathrm{~h}$ \\
\hline CV (\%) & 8.77 & 9.65 & 8.95 & 8.08 & 8.90 & 9.10 & 10.55 & 7.40 & 6.18 & 4.78 \\
\hline
\end{tabular}

Means having common letter in a column are not significantly different by DMRT at $5 \%$ level. 
The longest stalk lengths $(11.88,11.50$ and 11.68 $\mathrm{cm}$ ) were found from $\mathrm{T}_{3}$ treatment for each of the 3 years and it was significantly different from all other treatments for $1^{\text {st }}$ year but statistically identical with $\mathrm{T}_{4}, \mathrm{~T}_{2}$ and $\mathrm{T}_{10}$ for $2^{\text {nd }}$ year. In $3^{\text {rd }}$ year it was statistically identical with all other treatments except $T_{1}, T_{6}$ and $T_{11}$. Flower yield was also significantly influenced by different levels of N, P and K fertilizers (Table 3) and it was increased to a maximum of $12.45,11.80$ and 11.63 ton $\mathrm{ha}^{-1}$, respectively for $1^{\text {st }}, 2^{\text {nd }}$ and $3^{\text {rd }}$ year with NPK fertilizer application. Highest flower yield $\left(12.45,11.80\right.$ and 11.63 ton $\mathrm{ha}^{-1}$ respectively for the years) was obtained from the $\mathrm{T}_{3}\left(\mathrm{~N}_{150} \mathrm{P}_{75} \mathrm{~K}_{135} \mathrm{~kg} \mathrm{ha}^{-1}\right)$ treatment which were statistically similar to the treatment $\mathrm{T}_{4}$ $\left(\mathrm{N}_{200} \mathrm{P}_{75} \mathrm{~K}_{135} \mathrm{~kg} \mathrm{ha}^{-1}\right)$ for $1^{\text {st }}$ and $3^{\text {rd }}$ year but significantly different from all other treatment for $2^{\text {nd }}$ year. Average flower yield was also affected by the different nutrient levels and the maximum (11.96 ton ha ${ }^{-1}$ was obtained from $\mathrm{T}_{3}$ treatment that was significantly different from all other treatments. These results are in agreement with the findings of Chezhiyan et al. (1986), Lodhi and Tiwari (1993) and Rao et al. (1992). Application of $150 \mathrm{~kg} \mathrm{~N} \mathrm{ha}^{-1}, 75 \mathrm{~kg} \mathrm{P} \mathrm{ha}^{-1}$ and $135 \mathrm{~kg} \mathrm{~K} \mathrm{ha}^{-1}$ individually performed the highest yield of chrysanthemum (Table 3). Addition of nitrogen increased flower yield of 39.26, 52.76 and $46.63 \%$ by 100,150 and $200 \mathrm{~kg} \mathrm{~N} \mathrm{ha}^{-1}$, respectively for the years over control. Balanced dose of nitrogen, phosphorus and potassium seemed to have increased the vegetative growth, favorable for the synthesis of peptide bond, protein and carbohydrate metabolism that are essential for flower development (Boodly and Meyer, 1965). The effect of nitrogen was more pronounced as compared to that of $\mathrm{P}$ and $\mathrm{K}$. Flower yield of chrysanthemum was also increased progressively with added $\mathrm{P}$ and $\mathrm{K}$ fertilizer up to 75 and $135 \mathrm{~kg} \mathrm{ha}^{-1}$, respectively and further increase in $\mathrm{P}$ and $\mathrm{K}$ fertilizer tended to decrease flower yield. The average yield difference between the highest and the lowest yielding treatment was $65.19 \%$ and $60.75 \%$ in case of $\mathrm{P}$ and $\mathrm{K}$, respectively. The increased nutrient availability from phosphorus through phosphobacteria might have increased the various endogenous hormonal levels in the plant tissue, which was responsible for the enhanced pollen germination and tube growth, which ultimately increased the number of fruit plant ${ }^{-1}$ according to Rajagopal and Rao (1974).

\subsection{Economic comparison}

Average data pertaining to economic comparison is presented in Table 4. Maximum gross return (Tk. $5083000.00 \mathrm{ha}^{-1}$ ) was achieved with the treatment combination $\mathrm{N}_{150} \mathrm{P}_{75} \mathrm{~K}_{135} \mathrm{~kg} \mathrm{ha}^{-1}\left(\mathrm{~T}_{3}\right)$. The highest benefit cost ratio (5.54) was also found in the treatment $T_{3}$ followed by $T_{4}$ and $T_{2}$ and the lowest benefit cost ratio (2.44) was found in control treatment. It could be said that the treatment $\mathrm{T}_{3}$ with $150 \mathrm{~kg} \mathrm{~N}, 75 \mathrm{~kg} \mathrm{P}$ and 135 $\mathrm{kg} \mathrm{K}$ was the most economically viable doses for chrysanthemum production.

\subsection{Regression analysis}

Single effect of N, P and $\mathrm{K}$ on yield of chrysanthemum were shown in Table 5. From this table it was clearly observed that the maximum average yield (11.12 ton $\mathrm{ha}^{-1}$ ) was found with the application of NPK @ 150,75 and $135 \mathrm{~kg} \mathrm{ha}^{-1}$, respectively and similarly the maximum average yield increase also were $88.35,65.19$ and $60.75 \%$ for those NPK doses, respectively over control. Regression analysis of average yield of chrysanthemum was done to fit the quadratic functions for estimating the optimum levels of each nutrient over the different levels of NPK fertilizer (Fig.1). Dobermann et al. (2000) stated that the optimum rate of fertilizer application to a crop is that rate which produces the maximum economic returns at the minimum cost and can be derived from a nutrient response curve. It is evident from figure. 1 that yields of chrysanthemum increased with increasing level of fertilizer nutrients to a certain level and then decreased with further increase of nutrient level. The yield increment was prominent in case of $\mathrm{N}$ fertilizer application and the highest yield $(12.45,11.80$ and 11.63 ton ha ${ }^{1}$, respectively for the years) as well as the average highest yield $\left(11.96 \mathrm{t} \mathrm{ha}^{-1}\right)$ was obtained from $150 \mathrm{~kg} \mathrm{~N}, 75 \mathrm{~kg} \mathrm{P}$ and $135 \mathrm{~kg} \mathrm{~K} \mathrm{ha}^{-1}$, respectively. From Fig.1.a optimum and 
economic doses were found as 155 and 151.80 $\mathrm{kg} \mathrm{ha}^{-1}$ for $\mathrm{N}, 79.30$ and $77.68 \mathrm{~kg} \mathrm{ha}^{-1}$ for $\mathrm{P}$ and it was 118.75 and $115.70 \mathrm{~kg} \mathrm{ha}^{-1}$ for $\mathrm{K}$, respectively which could be suggested as a recommended doses for chrysanthemum production.

Table 4. Economic analysis of chrysanthemum production under different fertilizer treatments

\begin{tabular}{cccccccc}
\hline $\begin{array}{c}\text { Treatm } \\
\text { ents }\end{array}$ & $\begin{array}{c}\text { Fixed } \\
\text { cost } \\
\left(\text { Tk. ha }^{-1}\right)\end{array}$ & $\begin{array}{c}\text { Variable cost } \\
(\text { Tk. ha } \\
(\text { Fertilizer } \\
\text { only) }\end{array}$ & $\begin{array}{c}\text { Total } \\
\text { cost }(\mathrm{Tk} . \\
\left.\text { ha }^{-1}\right)\end{array}$ & $\begin{array}{c}\text { Yield } \\
\left(\mathrm{t} \mathrm{ha}^{-1}\right)\end{array}$ & $\begin{array}{c}\text { Price of } \\
\text { Chrysanthe } \\
\text { mum }(\mathrm{Tk} . \\
\left.\text { ton }^{-1}\right)\end{array}$ & $\begin{array}{c}\text { Gross return } \\
\left(\text { Tk. ha }^{-1}\right)\end{array}$ & BCR \\
\hline $\mathrm{T}_{1}$ & $8,92,500$ & 18,300 & $9,10,800$ & 6.35 & $4,25,000$ & $26,98,750$ & 2.96 \\
$\mathrm{~T}_{2}$ & $8,92,500$ & 22,700 & $9,15,200$ & 10.25 & $4,25,000$ & $43,56,250$ & 4.76 \\
$\mathrm{~T}_{3}$ & $8,92,500$ & 24,900 & $9,17,400$ & 11.96 & $4,25,000$ & $50,83,000$ & 5.54 \\
$\mathrm{~T}_{4}$ & $8,92,500$ & 27,100 & $9,19,600$ & 11.12 & $4,25,000$ & $47,26,000$ & 5.14 \\
$\mathrm{~T}_{5}$ & $8,92,500$ & 16,650 & $9,09,150$ & 7.24 & $4,25,000$ & $30,77,000$ & 3.38 \\
$\mathrm{~T}_{6}$ & $8,92,500$ & 22,150 & $9,14,650$ & 8.12 & $4,25,000$ & $34,51,000$ & 3.77 \\
$\mathrm{~T}_{7}$ & $8,92,500$ & 27,650 & $9,20,150$ & 8.86 & $4,25,000$ & $37,65,500$ & 4.09 \\
$\mathrm{~T}_{8}$ & $8,92,500$ & 18,690 & $9,11,190$ & 7.44 & $4,25,000$ & $31,62,000$ & 3.47 \\
$\mathrm{~T}_{9}$ & $8,92,500$ & 22,830 & $9,15,330$ & 8.98 & $4,25,000$ & $38,16,500$ & 4.17 \\
$\mathrm{~T}_{10}$ & $8,92,500$ & 26,970 & $9,19,470$ & 9.55 & $4,25,000$ & $40,58,750$ & 4.41 \\
$\mathrm{~T}_{11}$ & $8,92,500$ & - & $8,92,500$ & 5.13 & $4,25,000$ & $21,80,250$ & 2.44 \\
\hline
\end{tabular}

Labor + Seedling + Pesticide/insecticide + Irrigation $(37500+835000+5000+15000=357500 /-)$ Labor = $150 \times 250 /-=37500 /-$, Seedlings=83500 $\times$ @ 10/- =835000/-, Urea = Tk. $20 \mathrm{~kg}^{-1}$, TSP=Tk. $22 \mathrm{~kg}^{-1}, M o P=T k .23 \mathrm{~kg}^{-1}$, Boric Acid = Tk. $195 \mathrm{~kg}^{-1}$, Zinc Sulphate = Tk. $125 \mathrm{~kg}^{-1}$, Price of flower=@ Tk. $425 \mathrm{~kg}^{-1}$ flower

Table 5. Single effect of N, P and K on yield of chrysanthemum

\begin{tabular}{llccccccc}
\hline $\begin{array}{c}\text { Nutrient } \\
\text { level } \\
\left(\mathrm{kgha}^{-1}\right)\end{array}$ & \multicolumn{3}{c}{ Flower yield $\left(\mathrm{t} \mathrm{ha}^{-1}\right)$} & \multicolumn{5}{c}{ \% yield increase over control } \\
\cline { 2 - 9 } N level & $2012-13$ & $2013-14$ & $2014-15$ & Average & $2012-13$ & $2013-14$ & $2014-15$ & Average \\
\hline 0 & 8.15 & 4.88 & 6.02 & 6.35 & - & - & - & - \\
100 & 11.35 & 9.48 & 9.92 & 10.25 & 39.26 & 94.26 & 64.78 & 61.42 \\
150 & 12.45 & 11.80 & 11.63 & 11.96 & 52.76 & 141.80 & 93.19 & 88.35 \\
200 & 11.95 & 10.62 & 10.79 & 11.12 & 46.63 & 117.62 & 79.24 & 75.12 \\
\hline P level & & & & & & & & \\
\hline 0 & 8.75 & 5.40 & 7.57 & 7.24 & - & - & - & - \\
50 & 9.55 & 6.58 & 8.23 & 8.12 & 9.14 & 21.85 & 8.72 & 12.15 \\
75 & 12.45 & 11.80 & 11.63 & 11.96 & 42.29 & 118.52 & 53.63 & 65.19 \\
100 & 10.15 & 7.31 & 9.12 & 8.86 & 16.00 & 35.37 & 20.48 & 22.38 \\
\hline K level & & & & & & & & \\
\hline 0 & 9.12 & 6.09 & 7.11 & 7.44 & - & - & - & - \\
90 & 10.55 & 7.78 & 8.62 & 8.98 & 15.68 & 27.75 & 21.24 & 20.70 \\
135 & 12.45 & 11.80 & 11.63 & 11.96 & 36.51 & 93.76 & 63.57 & 60.75 \\
180 & 11.05 & 8.39 & 9.22 & 9.55 & 21.62 & 37.77 & 29.68 & 28.36 \\
\hline
\end{tabular}




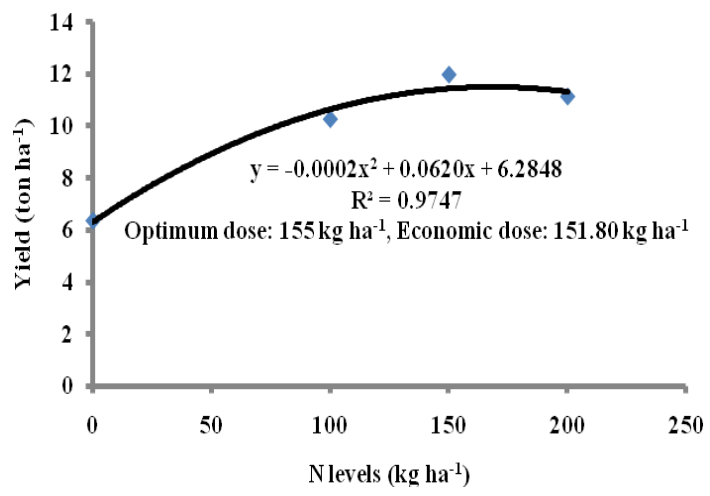

a. Optimum and economic dose of $\mathrm{N}$ for chrysenthemum production

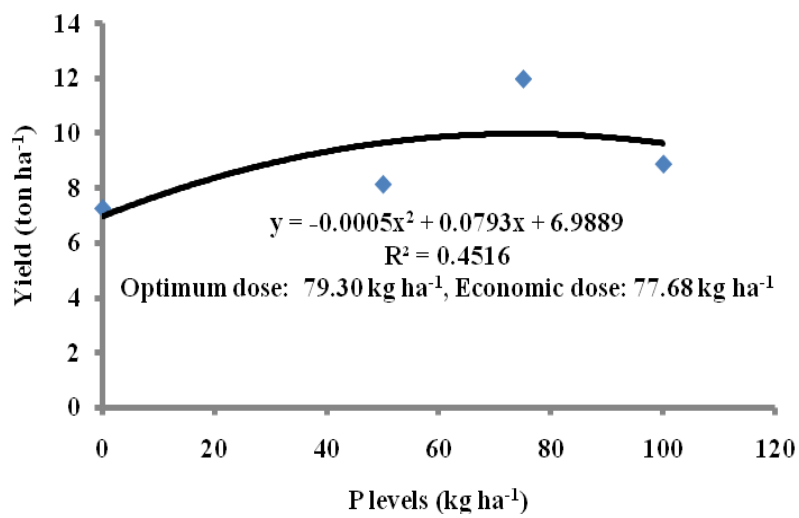

b. Optimum and economic dose of $\mathrm{P}$ for chrysenthemum production

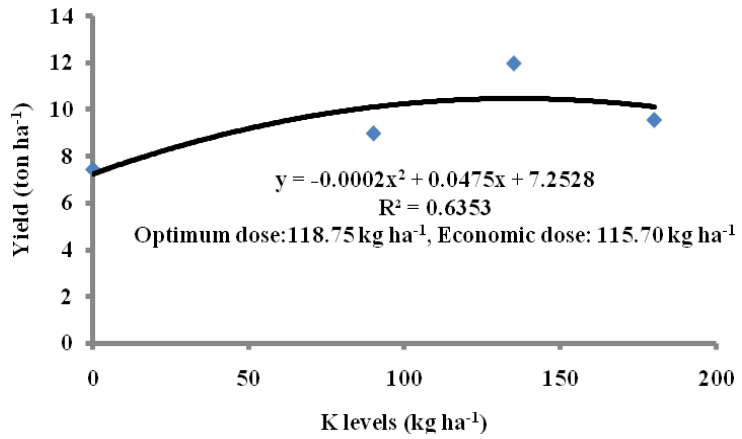

c. Optimum and economic dose of $\mathrm{K}$ for chrysenthemum production

Figure 1. Functional relationship between mean yield of chrysanthemum and different levels of N, P and $\mathrm{K}$. 


\section{Conclusions}

From three years study, results indicated that judicious nutrient management in chrysanthemum can ensure high profit. Application of 150-75-135 kg NPK ha ${ }^{-1}$ along with blanket dose of $2 \mathrm{~kg} \mathrm{~B}$ and $4 \mathrm{~kg} \mathrm{Zn} \mathrm{ha}^{-1}$ showed the best performance for chrysanthemum production. From quadratic regression equation averaging three years data $155 \mathrm{~kg} \mathrm{~N}, 79.3 \mathrm{~kg} \mathrm{P}$ and $118.75 \mathrm{~kg} \mathrm{~K} \mathrm{ha}^{-1}$ and $151.8 \mathrm{~kg} \mathrm{~N}, 77.68 \mathrm{~kg} \mathrm{P}$ and $115.7 \mathrm{~kg} \mathrm{~K} \mathrm{ha}^{-1}$, respectively were found as the optimum and economic doses which could be recommended for chrysanthemum production in Grey Terrace Soil of Joydebpur under AEZ 28.

\section{References}

Ahmed M, Khan MF, Hamid A. and Hussain, A., 2004. Effect of Urea, DAP and FYM on growth and flowering of Dahlia (Dahlia variabilis). International Journal of Agriculture and Biology, 6(2): 393-395.

Belorkar, P.V., Patel, B. N., Golliwar, V. J. and Kothare, A.J., 1992. Effect of nitrogen and spacing on growth, flowering and yield of African marigold. Journal Soils and Crops, 2: 62-64.

Boodly, J. W. and Meyer, J. R., 1965. The nutrient content of Bonnaffom deltue chrysanthemum from juvenile to mature growth. American Society of Horticultural Science, 87: 472-478.

Chezhiyan, N., Nanjan and Abdul Khader, Md., 1986. Studies on nutrient requirement of chrysanthemum indicum cv. co.-1. South Indian Horticulture, 34: 173-178.

Denisen, E.L., 1982. Principal of Horticulture. Macmillan Publishers, Co., New York, 409-412 pp.

Dhaka, R.S., M.S. Fageria, S. Mohemmed, A.S. Faroda, N.L. Joshi, S. Kathju and K.
Amal, 1999. Effect of different levels of $\mathrm{N}, \mathrm{P}$ and $\mathrm{K}$ on floral characters of zinnia. SKN College of Agriculture, Jaipur, India, 379-382 pp.

Dobermann, A. and Fairhurst, T., 2000. Economics of fertilizer use rice-Nutrient disorder and nutrient management. Potash and phosphate Institute, Canada and International Rice Research Institute, Philippines, $38 \mathrm{p}$.

Haque, I. and Jakhro, A. A., 2001. Soil and fertilizer potassium. In "Soil Science" National Book Foundation, Islamabad, Pakistan, 261-263 pp.

Henry, D., 1982. Effect of potassium on plant growth. Journal of Ornamental Horticultural Science, 6:320-321.

Jhon, A. Q. and Paul, T. M. 1999. Response of Chrysanthemum morifolium ramat to different levels of nitrogen and phosphorus. Applied Biological Research, 1(1): 35-38.

Kazimirova, R. N., 1975. Certain characteristics of chrysanthemum mineral nutrition. Gosadarate Vennogo Nikitakaqo Suda, 3: 74-77.

Khan, M. A., Malik, A. B., Khan, M. N. and Saeed, T., 1999. Nitrogen fertilizer in Zinnia elegans in pot culture. Pakistan Journal of Science and Research, 3: 8184.

Khankhane, R. N.; Damke, M. M.; Jadhao, B. J. and Hadau, C. V., 1997. Growth, flowering and yield of chrysanthemum cv. 'Yellow Bijali' as influenced by nitrogen and phosphorus fertilization. $P K V$ Research Journal, 21(1): 48-52.

Kochkin, M. A. and Kazimirova, R. N., 1971. Changes in the available forms of 
nutrients in the soil during chrysanthemum growing. Trudy Gosudarstvennogo Nikitskogo Botanicheskogo Sada, 53: 59-71.

Konnerup, D. and Brix, H. 2010. Nitrogen nutrition of Canna indica. Effects of ammonium versus nitrate on growth, biomass allocation, photosynthesis, nitrate reductase activity and $\mathrm{N}$ uptake rates. Aquatic Botany, 92: 142-148.

Li Y., Jiang Y., Li Z. and Zhao L., 2009. A study of phosphorus uptake kinetic characteristic of four terrestrial economic plants. In: Proceedings of Beijing International Environmental Technology Conference, Beijing, 140-145 pp.

Liu W., Zhu D.W., Liu D. H., Geng M. J., Zhou W. B., Mi W. J., Yang T.W. and Hamilton D., 2010. Influence of nitrogen on the primary and secondary metabolism and synthesis of flavonoids in Chrysanthemum morifolium. Journal of Plant Nutrition, 33: $240-254$

Lodhi, A. K. S. and Tiwari, G. N., 1993. Nutritional requirement of chrysanthemum under field condition. Fertilizer News, 38(3): 39-45.

Meyer, B. S., Banderson, D., Bohning, R. H. and Fratianne, D.G., 1973. Introduction to Plant Physiology. D. Van Nostrand Companey, New York, 193-322 pp.

Mishra H. P., 1998. Effect of nitrogen on growth and flowering of Gaillardia. Indian Journal of Ornamental Horticulture, 1: 41-47.
Rajagapal, V. and Rao, I. M., 1974. Changes in the Endogenous Level of Auxins and Gibberellin-Like Substances in the Shoot Apices of Nitrogen-Deficient Tomato Plants (Lycopersicon esculentum Mill). Australian Journal of Botany, 22(3): 429435.

Rao, D. V. R., Balasubramanyam, S. A., Reddy, K. B. and Suryanarayana, V., 1992. Effect of different spacing and nitrogen levels of growth and flower yield of chrysanthemum cv. Kasturi. South Indian Horticulture, 40(6):323-328.

Song X.X., Zheng C.S., Sun X. and Ma H.Y., 2011. Effects of controlled-release fertilizer on chrysanthemum leaf chlorophyll fluorescence characteristics and ornamental quality. Chinese Journal of Applied Ecology, 22: 1737-1742.

Vaněk V., Balík J., Černý J., Pavlík M., Pavlíková D., Tlustoš P. and Valtera J., 2012. The Nutrition of Horticultural Plants. Academic Press, Prague, 568 p.

Yoon H. S., Goto T. and Kageyama Y., 2000. Mineral uptake as influenced by growing seasons and developmental stages in spray chrysanthemums grown under a hydroponic system. Journal of the Japanense Society for Horticultural Science, 69: 255-260.

Zhang, W., Li, X., Chen, F. and Lu, J. 2012. Accumulation and distribution characteristics for nitrogen, phosphorus and potassium in different cultivars of Petunia hybrida Vlim. Science in Horticulture, 141: 83-90. 